Ritrýnd grein birt 31. desember 2021

\title{
Let them wonder: Incubation and task constraints in creative problem solving
}

\author{
Póra Óskarsdóttir and Elsa Eiríksdóttir \\ Abstract $\longrightarrow$ Um höfunda $\longrightarrow$ About the authors $>$ Heimildir
}

Including incubation periods when solving creative tasks; that is, setting the task temporarily aside, has been shown to benefit creative problem solving in experimental settings. However, practical implications and benefits of incubation are unclear, especially in a school setting. An important factor involves the difference between how creative problems are defined in an experimental situation, on the one hand, and an applied context, such as schools, on the other. Creative problems in incubation experiments are typically clearly defined tasks, but such well-defined problems are rarely found in practical situations where ambiguous problems with multiple solutions are more likely. For incubation to be relevant in an applied setting, such as schools, it is vital to understand the role of how tasks are defined. The aim of the current study was to assess whether having a highly constrained task is necessary for incubation periods to benefit creative problem solving. An experiment with two fully crossed independent variables, incubation period (included and not included) and task constraints (high and medium) was used to investigate the effects on both creative originality and creative productivity. Task constraints were implemented by first allowing participants to select their task and then later allowing half of the participants to revise their choice. An incubation period was implemented by interpolating a choice reaction task into the creative task for half of the participants. The results demonstrate that clear unchangeable tasks are necessary for incubation to benefit creative problem solving. Choice must, therefore, be constrained before the task is temporarily set aside, for incubation to benefit creativity. For practical applications in a school setting, this means that students should be encouraged to select a task or settle on an idea early in the process of completing a creative assignment to benefit from incubation periods.

Keywords: Creativity, incubation, spontaneous thought, task constraints, choice, problem solving

\section{Introduction}

In the past few decades, creative projects in schools have increasingly become a larger part of formal education (Glăveanu \& Kaufman, 2019). Creativity is a segment of what has been coined 21st century skills and is specifically emphasized in the Icelandic curriculum (Ministry of Education, Science, and Culture, 2012). While interest in creative projects has grown in education, a common definition of what this entails is difficult to find. A creative solution is defined as a novel and appropriate solution to a problem (Glăveanu \& Kaufman, 2019). Thus, the solution is surprising, but makes sense at the same time; a clever solution that works in a better way than anticipated. However, the standards for creativity vary in important ways between subjects (Patston et al., 2018). It seems unlikely that an arts teacher and a biology teacher are asking for the same thing when they want their students to be creative. Creativity, as a skill and part of a curriculum, needs to be learned, applied, and assessed. For 
practical school settings it is important to ascertain which methods develop creative skills and which might have unintended negative consequences. One important aspect of enhancing creativity in the classroom is framing, where teachers try to balance between freedom and control (Jónsdóttir, 2017). Here teachers must evaluate how constraints affect creativity, and what type of framing and projects are appropriate for students (Jóhannsdóttir et al., 2012). Providing students with different and varied opportunities to demonstrate and practice their creativity in the course of everyday schoolwork could be more beneficial to learning than giving them occasional grand creative projects.

Creativity has been described as an ordinary cognitive process with extraordinary results (Ward $\&$ Kolomyts, 2019). Albeit a process that may not always be encouraged. Thinking involves both focused attention, which teachers encourage in the classroom, but also spontaneous thought, such as mind wandering. Mind wandering tends to gravitate towards day-to-day activities such as worries, future projects, and uncompleted schoolwork (Klinger et al., 2018). Mind wandering is generally discouraged in the classroom as it drags the attention away from coursework. The scientific term for mind wandering is spontaneous thought. Spontaneous thought also encompasses other processes aside from mind wandering, such as unconscious thought, daydreaming and rumination (Christoff et al., 2016). It is during such spontaneous thought processes that creative ideas tend to flourish, and incubation takes place. Incubation is defined as "the gradual generation of a solution to a problem at an unconscious or semiconscious level, often after an attempt at a conscious, deliberate solution has failed" (American Psychological Association, n.d.). Research has shown that incubation results in more original ideas and those working on creative projects often use spontaneous processing to their advantage by setting uncompleted projects aside and thus creating the opportunity for incubation (Liu et al., 2017). This sometimes leads to highly creative ideas, but it can also backfire and lead to procrastination and missed deadlines.

In incubation experiments highly restricted tasks are generally used to measure creativity, such as the alternate uses task (AUT) where participants are asked to come up with alternate creative uses for commonplace objects such as a paperclip (Dodds et al., 2012; Sio \& Ormerod, 2009). In contrast, creative projects in schools usually offer a lot of freedom in defining the task and projects as this is expected to enhance the agency of the student (Jónsdóttir, 2017). Creativity can thrive within constraints; it is more a matter of how constraints are used to support creativity and when (Beghetto et al., 2016). Creative projects and tasks in a school setting and experimental settings are, therefore, very different. In school projects it is possible that projects with late deadlines will allow incubation to take place benefiting creativity. A late deadline will engage spontaneous processing of the project intermittently until the project is turned in (Smallwood \& Schooler, 2006; Stawarczyk et al., 2013). It is, however, unclear why spontaneous processing results in incubation and improved creativity and no other forms of spontaneous thought such as ruminating. As incubation gains have been demonstrated in experimental settings it is possible that part of the answer lies in the experimental conditions themselves.

The largest difference between creative tasks in the classroom and tasks in experimental research is choice. In a classroom, students typically can choose their task, whereas in highly controlled experiments participants rarely can, as choice adds complexity to the data. However, research has shown that an incubation period in an experimental setting does enhance creativity (Sio \& Ormerod, 2009). The question becomes: How can beneficial creative processes, such as incubation, be purposefully applied in the classroom? In particular, as spontaneous thought can be both beneficial for creativity; that is, incubation, and detrimental when it turns into worry and rumination. An important aspect is to find out how constrained a creative task needs to be, for incubation gains to be expected? The controlled task constraints seen in experiments on creative problem solving might be an important condition for incubation to enhance creativity. It is not known how choices affect incubation, specifically when the choice can be changed at the last-minute. Deciding what to work on, or choosing the task, adds ambiguity to the situation and may interrupt the cognitive processing of a creative task. For incubation to be purposefully applied in school settings, task constraints such as choices in selecting and defining tasks, must be explored in the context of incubation. Therefore, the influence of task constraints and choice on creative problem solving during incubation will be the focus of the current study. 


\section{The creative cognitive process}

In the dominant cognitive model of creativity, the Wallas model, the creative process consists of four-stages: Preparation, incubation, illumination, and verification (Benedek \& Jauk, 2019; Mednick et al., 1964; Sadler-Smith, 2015; Wallas, 1926). This model identifies the reciprocal relationship of cognitive control and spontaneous thought in creativity. Cognitive control refers to deliberate conscious attention, whereas spontaneous thought is not under deliberate control and can be distracting. During the first stage, preparation, cognitive control is needed as conscious attention is used to work on the task. In the second stage, incubation, spontaneous thought is important, but preparation is a necessary precursor. When a solution is realized, illumination occurs (the third stage). The last stage, verification, the process shifts back to cognitive control, and the solution is produced or tested (Benedek \& Jauk, 2019; Ward \& Kolomyts, 2019). For example, when assembling furniture such as IKEA shelves the preparation stage involves conscious cognitive control and attending to relevant information such as the instructions and where to find the necessary tools. Now imagine that the furniture does not fit as intended. This is frustrating so you leave the task and start doing the dishes. This shifts conscious processing from assembling furniture to washing dishes, which is a largely automated task, freeing cognitive resources for undirected spontaneous processing such as incubation. While doing the dishes, your thoughts wander to the furniture problem buzzing in the back of your mind. Then suddenly illumination and a possible solution to the furniture problem pulls your attention away from the dishes and you return to the furniture assembly to test the solution out. Now conscious attention is focused back to the furniture problem in the final verification stage.

Out of these four stages, the incubation stage has gained most interest in creativity research, but nevertheless, the importance of cognitive control during the first and last stages of the process cannot be overlooked. Preparation and verification rely on cognitive control to facilitate creative production, allowing people to produce their discoveries. Effective conscious processing during the preparation period may be a necessary precursor to incubation (Howe et al., 2005; Ward \& Kolomyts, 2019; Ward et al., 2004). Clear and constrained tasks allow effective conscious processing that promotes learning and task performance (Eiriksdottir \& Catrambone, 2011). Clear specific goals consciously processed during the preparation period set the stage for the incubation period by activating spontaneous cognitive resources that continue the same trajectory of processing during a break (Berg, 2014; Bos et al., 2008; Ritter \& Dijksterhuis, 2014); allowing the mind to drift productively towards a goal, instead of aimless mind wandering (Christoff et al., 2016; Kam et al., 2013; Killingsworth \& Gilbert, 2010; Krys et al., 2020; Stawarczyk et al., 2013). Think of pushing a raft from shore, the push affects the trajectory as well as conditions on the lake itself. In the same vein, uncertainty about a goal could be seen to maintain mind wandering in its most recognized state, as task irrelevant thinking that can be disruptive to optimal functioning. Here the raft receives no push from shore and is only affected by the conditions on the lake.

\section{Incubation}

The incubation effect is a robust effect generally found in divergent thinking and insight problem solving experiments (Sio \& Ormerod, 2009). Incubation periods result in better problem solving of the task than conscious deliberate work and the effect is even stronger during creative problem solving. The incubation effect has been researched quantitatively in cognitive experiments (Sio \& Ormerod, 2009) and neuroimaging studies (Beaty et al., 2015; Zabelina \& Andrews-Hanna, 2016). In cognitive experiments the incubation period is produced by interrupting a creative task, with a different task. When these tasks split up the creative task to make an incubation period, they are called interpolated tasks. Incubation gains are stronger when the interpolated task is unrelated to the creative task (i.e. verbal vs. numerical) than when the tasks are similar (Gilhooly et al., 2013). The main purpose of interpolated tasks is to inhibit deliberate conscious work on the creative problem (Baird et al., 2012) instead providing an opportunity for spontaneous processing. 
Interpolated tasks vary in their complexity and demands on conscious processing, ranging from low to high cognitive processing demands. Research suggests that tasks with lower cognitive processing demands bring the greatest incubation gains, and better performance in comparison to either resting or deliberately working on the problem (Baird et al., 2012; Sio \& Ormerod, 2009). An incubation period filled with a low cognitive load can even benefit two AUT problems simultaneously (Baird et al., 2012).

Various cognitive processes have been suggested to account for the incubation effect, but the main question has revolved around whether incubation is an active or passive cognitive process. Mounting evidence suggests that active cognitive processes are important during the incubation period. For example, research has shown that the incubation gains are stronger if people are aware that they will continue working on the problem after the interruption (Gallate et al., 2012). Additionally, incubation gains will not be seen if the creative task unexpectedly changes after the incubation period (Baird et al., 2012). Moreover, it seems that incubation requires cognitive resources (Dodds et al., 2012; Gilhooly, 2016; Gilhooly et al., 2013). It is, therefore, likely that incubation gains are due to ongoing active cognitive processing during the incubation period, also known as spontaneous thought or processing.

As incubation may be a unique positive result of spontaneous processing, this effect is probably the outcome of specific circumstances. When people are interrupted during a task or given time to mind wander it is more likely that they will just be bored, distracted and not very creative (Klinger et al., 2018). The projects that people have been or are currently working on clearly influence spontaneous processing (Baird et al., 2012). It seems that if the tasks are well defined with clear goals, mind wandering takes the form of spontaneous processing and incubation, but if the tasks are ill-defined with unclear goals, mind wandering remains in its most recognized state, as task irrelevant thinking (DuPre \& Spreng, 2018; van Vugt et al., 2018).

\section{Goals, task constraints and incubation}

It is well established that spontaneous thought or mind wandering is related to the individual's goal pursuits (Klinger et al., 2018) and goal monitoring is largely unconscious (Bos et al., 2008). A goal describes the desired results of a task or the reason why people are working on the task. Tasks are the activities undertaken to reach a goal, that is the behaviors themselves (planning and organizing are also behaviors in this sense). Goals strongly influence behavior, attention, and motivation, leading to better performance on tasks (Locke, 1996; Locke \& Latham, 2006). When a high-level goal is paired with unspecific tasks, goals are less likely to be achieved. Clear tasks break goals down into smaller achievable sub goals and are more likely to be pursued and completed. Completing tasks allows people to monitor their progress towards their goals (Krys et al., 2020). Goals organize cognitive processing from more important work "clear goals" to less important "unclear goals" (Klinger et al., 2018). This also applies to creative tasks (Madjar \& Shalley, 2008; Shalley, 1991).

Given the role of goals in spontaneous thought, (Bos et al., 2008) and the proposed link between spontaneous thought and incubation (Benedek \& Jauk, 2019; Ritter \& Dijksterhuis, 2014; Simonton, 2018) it is surprising that task specificity while pursuing a goal has not gained much attention in incubation research. Previous experiments have provided evidence about the goal dependency of spontaneous thought during problem solving (Bos et al., 2008; Dijksterhuis et al., 2006; Gallate et al., 2012). But in the experiments the "goals" are so specific it could also be argued that they are specific tasks. Examples of these goals are "make a good decision about roommates" or "find alternative uses for a paper clip". This indicates that the specificity of the task and not the goal itself is the key to better performance. All participants had shared goals; that is, to provide good decisions or creative responses after an incubation period. What distinguished more successful participants from the others is that they knew what tasks they would work on to achieve the goal (Bos et al., 2008); they had worked on the task before (Baird et al., 2012) and expected to work on it again (Gallate et al., 2012). That is, the task was known, well defined and constrained. When participants are surprised 
with new tasks or the task is changed, incubation benefits are not seen (Baird et al., 2012). Here a creative task could change from finding alternate uses for a paperclip or a towel, but the goal remains the same "be creative in finding alternative uses". This indicates that spontaneous cognitive work on a specific and constrained task, and not the goal itself, plays a part in successful incubation.

\section{The present study}

The current experiment tested how task constraints affect incubation periods and creative problem solving on two measures of creativity - creative originality and creative productivity. Creative originality is a measure that captures the most creative ideas (the top three index) while creative productivity is more sensitive to the number of ideas generated (Benedek et al., 2013; Silvia, 2011).

Incubation periods were expected to enhance creative problem solving only if the task was highly constrained. Half of the participants experienced an incubation period after the practice trial and before the test trial while the other half did not. High task constraints were expected to benefit both measures. Task constraints are implemented through the choice of tasks: The participants either permanently chose the task before the practice trial or had the option of changing their choice after. Having a permanent choice was expected to make the task more specific and restrict spontaneous processing in a beneficial way during the practice trial and incubation period. Alternately, when the task can be changed, spontaneous processing during the incubation period was expected to engage in comparing tasks, instead of generating new and varied solutions. A clear unchangeable task was therefore expected to create the context needed for incubation during creative problem solving. The research questions posed were the following.

Research question: Are high task constraints important to facilitate incubation gains?

Hypothesis 1: Task constraints interact with incubation periods such that high task constraints create the context for incubation gains, as measured with creative originality. That is, (a) incubation gains will be present in groups with highly constrained tasks and (b) incubation gains will be reduced when tasks have medium constraints.

Hypothesis 2: Task constraints interact with incubation periods such that medium task constraints create the context for interference, as measured with creative productivity.

The central hypothesis of this experiment is that by constraining the choice of AUT problems, creative incubation gains are made possible. Constrained creative tasks benefit the understanding of the task and ease conscious processing, increasing measures of creative productivity. When a clear task is then set aside during incubation periods, spontaneous processing can work towards finding creative solutions, resulting in higher measures of creative originality.

\section{Method}

\section{Participants}

Participants were 69 students in Fjölbrautaskólinn í Breiðholti (FB), a comprehensive upper secondary school offering both vocational and academic programs. Five participants were excluded from the dataset, three because of substantial missing data (tasks were incomplete), one participant misunderstood the instructions and the task, and one participant left the experiment. The final sample therefore consists of 64 students ( 28 women, 31 men, 5 chose not to disclose their gender) with a mean age of 19.5 years (17-34). There were altogether 4 sessions where 15-18 participants completed the experiment at the same time. Within each group, participants were randomly assigned to one of the four experimental conditions. 


\section{Design}

To determine the effects of task context on creative incubation gains the two independent variables (task constraints and incubation period) were manipulated in a $2 \times 2$ between-group experimental design, creating four conditions (see Table 1). Each participant received one level of each independent variable. The first independent variable was task constraints where half of the participants could change the choice of the AUT object (medium constraints) while the other half could not (high constraints). The second independent variable was an incubation period; where a cognitively undemanding task (a choice reaction task) was either interpolated between the practice AUT and test AUT trials (incubation period) or completed before them (no incubation period).

Table 1. The experimental design.

\begin{tabular}{|c|c|c|c|}
\hline & & \multicolumn{2}{|c|}{ Task constraints } \\
\hline & & High & Medium \\
\hline \multirow{4}{*}{ Incubation period } & No & HighConstraints- & MediumConstraints \\
\hline & NO & NoIncubation $(n=16)$ & -NoIncubation $(n=15)$ \\
\hline & $y$ & HighConstraints- & MediumConstraints- \\
\hline & ICS & Incubation $(n=16)$ & Incubation $(n=17)$ \\
\hline
\end{tabular}

Performance on the AUT task was measured with creative originality and creative productivity. Creative originality assesses how well the participants could generate original ideas and was measured with the top three index (Benedek et al., 2013; Silvia, 2011). In this measure, one rater, blind to the experimental conditions, is responsible for selecting the three best ideas from each participant. These three best ideas are then rated by three different independent raters and their score averaged for each participant. Creative productivity involves taking both the quality of the ideas and the quantity generated into account and is measured by scoring all independent ideas (no duplicates) generated by each participant and then adding these scores together. The participants were asked to generate as many creative ideas as possible during the AUT test. The creative productivity measure is, therefore, consistent with the instructions provided on the AUT trials.

Note that the two dependent measures do not necessarily correlate; someone who scores low on creative productivity can score high on creative originality. This could happen if they provided very few, but highly creative, responses. By contrast, someone who scores very low on creative originality could attain a high creative productivity score if they responded with many yet uncreative solutions.

\section{Procedure}

All participants completed the experiment on individual and identical computers in a computer classroom. A research assistant greeted the participants and instructed them to their assigned computer. Participants were informed at the start of the experiment that they would be taking a test designed to measure creativity. All instructions on the specific procedures were provided electronically on the individual computers, guaranteeing that each participant only received instructions intended for the condition they were assigned to. If they had any questions, they were instructed to ask the research assistant by raising their hand.

The participants first completed a questionnaire collecting demographic information (see Figure 1 for an overview of the procedure). Afterwards, the groups without incubation periods (HighConstraints-NoIncubation and MediumConstraints-NoIncubation) completed the interpolated choice reaction task. The AUT instructions then appeared on the screen. The task was described as a creativity test and said to involve finding creative alternate uses for a common object. Examples were provided and the scoring was explained. A creative alternate use was defined as a novel yet logical way to use the object; easily recognized as a surprise that makes sense. After reading the AUT instructions the 
participants selected the two objects to use in the AUT task. The instructions reported that it was important to select the two objects they liked best as this would probably affect their performance. These objects would be used in the practice trial. The participants could choose from the following items: A balloon, a flowerpot, a towel, and a drinking straw.

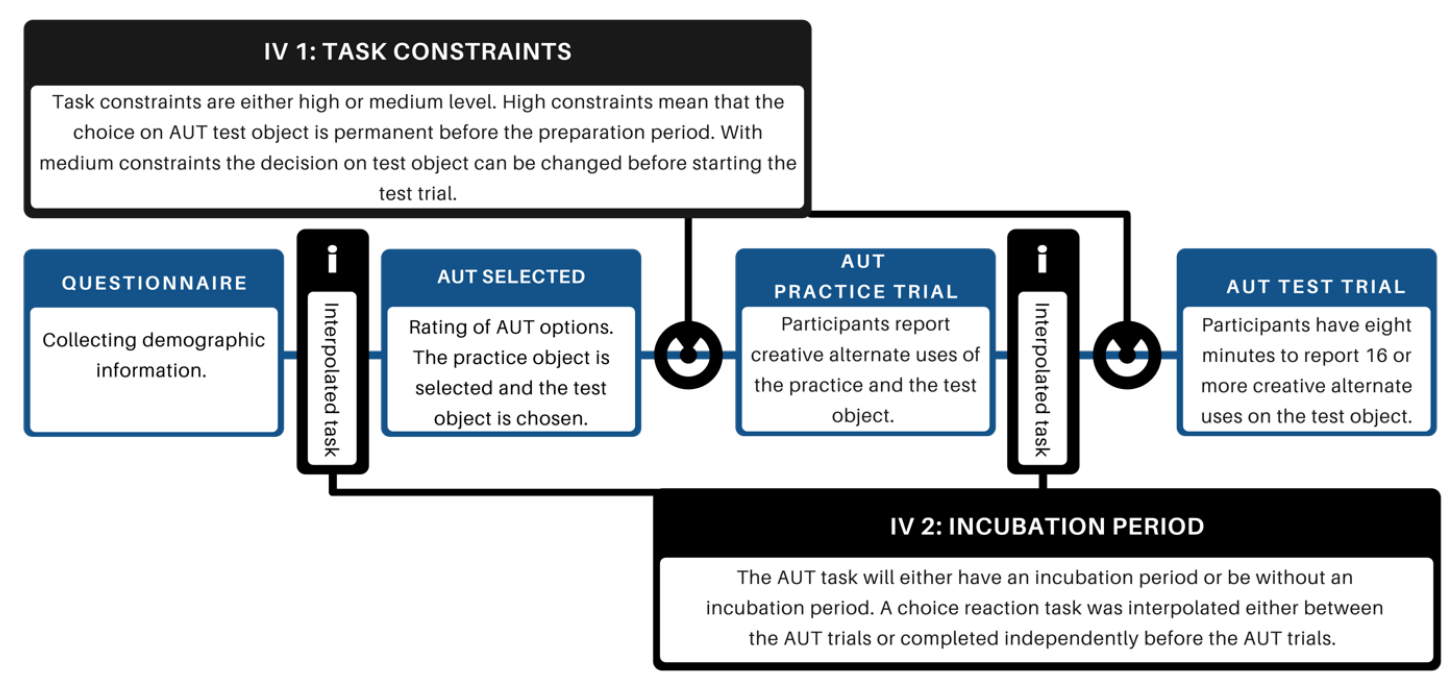

Figure 1. The experimental procedure.

Task constraints manipulation: The two selected objects were presented, and the participants were asked to choose the object they wanted to use for the test trial of the AUT task (post- incubation trial).

a) High task constraints: When selecting the object to use in the AUT test, participants in the high constraints condition (HighConstraints-Incubation and HighConstraints-NoIncubation) were told that this choice was final. They were told to make sure that the choice was right for them as the decision could not be changed.

b) Medium task constraints: When selecting the object to use in the AUT test, participants in the medium task constraints condition (MediumConstraints-Incubation and MediumConstraints-NoIncubation) were informed that if they changed their mind, they could easily switch to their other object before starting the test trial.

The experiment then proceeded to the AUT practice task where all participants provided two alternate uses for each of the two objects originally selected.

Incubation manipulation. The choice reaction task was interpolated at this point for the two groups with incubation periods (HighConstraints-Incubation and MediumConstraints-Incubation) while the other participants proceeded to the AUT test trial immediately.

Opening the AUT test. When the AUT test started, both objects were visible on the screen. A text appeared on the screen reminding participants of their choice "you chose the balloon and not the flowerpot".

a) In the high constraints condition (HighConstraints-Incubation and HighConstraints-NoIncubation) participants could only see the images and text reminding them of their choice and start the task.

b) In the medium constraints condition (MediumConstraints-Incubation and MediumConstraints-NoIncubation), the images were buttons with the text "click on the object you want to use in your creativity test". If nothing was changed, the participants would proceed to the test using the object they originally selected by default. 
In the AUT test trial participants responded with creative alternate uses to their selected test object. The test trial was 8 minutes long, and the test object and instructions were visible on the computer screen. The text instructed participants to be as creative as possible, but to come up with at least 16 answers. The program automatically closed the test and collected all responses after 8 minutes; the test could not be turned in before the 8 minutes were up. After completing the experiment, the participants moved to a meeting room where they were debriefed.

\section{Materials and tasks}

Lab setup: The experiment took place on 22 near identical campus computers and participants could only see their own screen.

Computer software: Gorilla Experiment Builder was used to create and host this experiment (Anwyl-Irvine et al., 2020). The computers used the Windows 10 operating system, and the experiment ran on a Chrome browser.

Questionnaire: At the beginning of the experiment, a short four item questionnaire collected demographic information: age, gender, education, and what course of study they majored in.

Interpolated task: The choice reaction task was adapted from Baird et al. (2012) as this is a cognitively undemanding task that has demonstrated high levels of mind wandering (Smallwood \& Schooler, 2015). The task consisted of numeric digits from 1-9 presented on screen for 1.5 seconds, separated by a 0.5 second fixation cross. The numbers were either red or green, half of them odd numbers. The task presents 81 green non-targets, 36 red non targets and 35 red targets. Participants were told to press the space button whenever a target (red number) was also an odd number. The task would measure their response time and record their responses.

Alternate uses tasks (Dodds et al., 2012; Runco et al., 2010; Torrance \& Haensly, 2003). Participants were instructed to respond with as many creative uses as possible, but to aim for at least 16 ideas. The test closed automatically after 8 minutes and collected all responses. The number of independent ideas ranged between $6-27(M=15.13 ; S D=4.67)$.

\section{Data preparation}

Preparing responses for rating: The participants generated 1051 responses. All responses were coded, pooled, and sorted by test object.

Rating: Five teachers served as raters and were trained by explaining the requirements of novelty and appropriateness of a creative solution. One teacher only selected the top three ideas for each participant whereas the other four scored the responses on a 5-point Likert scale. Three raters scored the responses for the top three index measure. One rater scored all responses for the creative productivity measure.

Creative originality (top three index): The interrater reliability between the three judges scoring the top three index was high with ICC $=.840(95 \%$ CI $[.759, .897])$. This is above the required ICC of .8 that is needed to be considered a valid measure (Benedek et al., 2013; Silvia, 2011). This measure is highly robust to the number of ideas generated; the correlation was $r=-.13(p>.05)$ A residual analysis revealed that the data was normally distributed in all groups assessed by Shapiro-Wilk's test $(p>.05)$. A residual boxplot for each experimental group revealed four outliers, but when all four groups were combined these values were no longer recorded as outliers. These values were, therefore, kept in the dataset, especially as the top three index involves identifying the best three ideas from each participant. Extreme measures are to be expected as some participants generate highly original ideas while others do not. 
Creative productivity: A residual analysis using Shapiro-Wilk's normality test for each cell of the design, showed that the data was normally distributed in all groups $(\mathrm{p}>.05)$. Two outliers were found in a boxplot. These outliers skewed the data in important ways by raising p values of the tests. This measure is highly sensitive to the number of ideas generated $(\mathrm{r}=.86 ; \mathrm{p}<.001)$. We considered adjusting these outliers, but since the outliers in the creative originality measure were not adjusted, these outliers were kept in the dataset unchanged.

The two creativity measures assess different aspects of creativity and correlations should therefore be low. The top three index is used to assess creative originality that relies more on spontaneous processing. Creative productivity relies more on conscious thought, allowing participants to strategize and follow through with the task. As expected, the correlation between creativity originality and creative performance was low $(r=.10)$ and not significant $(p>.05)$.

\section{Results}

The research question focused on whether high task constraints were important to facilitate incubation gains, and the hypotheses were two - one for each measure of creativity. The results for creative originality (top three index) will be reported first and then the results for creative productivity.

\section{Creative originality}

The creative originality scores ranged from 1.56-4.11 overall. The pattern of results indicates an interaction effect as the group with a highly constrained task and an incubation generated the most original responses of all four groups (see Figure 2).

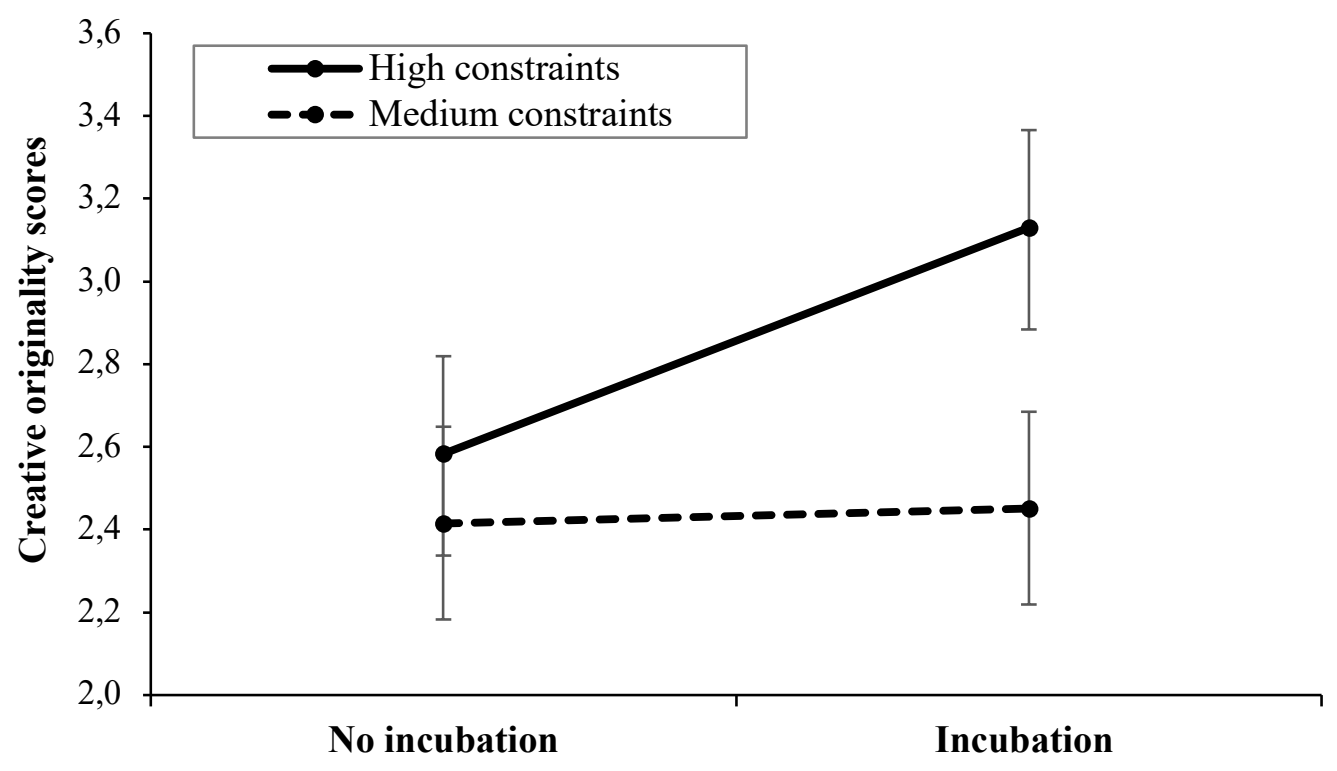

Figure 2. The effects of task constraints and incubation on creative originality scores.

The interaction between task constraints and incubation periods was found to be significant (see Table 2; $d=0.54$ ). Generally, both independent variables influenced the creative originality score (see Table 2). The creative originality score of groups with a highly constrained task was almost a whole standard deviation above the groups with a task of medium constraints $(d=0.91)$. Solutions were also more original for the groups who worked on tasks with an incubation period, compared to the groups who worked on tasks without incubation $(d=0.62)$. 
Table 2. Summarizes the two-way ANOVA statistics for creative originality.

\begin{tabular}{lccccc}
\hline \hline & \multicolumn{5}{c}{ ANOVA } \\
\cline { 2 - 6 } Creative originality & $\mathrm{N}$ & $d f$ & $F$ ratio & sig. & $\eta^{2}$ \\
\hline Interaction $(\mathrm{I} x \mathrm{C})$ & 64 & 1 & 4.41 & $.040^{*}$ & 0.07 \\
Constraints (C) & 64 & 1 & 12.25 & $.001^{* *}$ & 0.17 \\
Incubation (I) & 64 & 1 & 5.76 & $.020^{*}$ & 0.09 \\
\hline${ }^{*} p<.05,{ }^{* *} p<.001$. & & &
\end{tabular}

As the interaction was significant, the mean difference between groups (Table 3) was explored further with pairwise comparisons. These comparisons are Bonferroni adjusted for four comparisons. Statistical significance (alpha-values) for these comparisons is set at $p<.0125$.

The effect of incubation periods was explored by comparing the two groups that worked on highly constrained tasks (the HighConstraints-NoIncubation and HighConstraints-Incubation group). The best ideas generated in the high constraints condition were significantly more original $(F(1,60)$ $\left.=10.14, p=.002, \eta^{2}=.15\right)$ when an incubation period was included compared to when it was not $(d=0.82)$. Including an incubation period when working on a highly constrained task increased the mean creative originality scores by 0.47 on average $(S D=0.18)$.

The effect of task constraints was explored by comparing the two groups who had incubation periods and worked on either medium or highly constrained tasks (the HighConstraints-Incubation and MediumConstraints-Incubation groups). Incubation gains were significantly reduced $(M=-0.67, S D$ $=1.68)$ when tasks had medium constraints $\left(F(1,60)=16.18, p=.001, \eta^{2}=.21\right)$ as compared to high constraints $(d=-1.04)$. This confirms that incubation periods are less beneficial to creative originality when tasks are less constrained, and the results show that this difference is substantial.

Table 3. Means, standard deviations and confidence intervals for the creative originality measure.

\begin{tabular}{lcccccc}
\hline & \multicolumn{5}{c}{ Creative originality (top three index) } \\
\cline { 2 - 7 } & \multicolumn{2}{c}{ No incubation } & \multicolumn{2}{c}{ Incubation } & \multicolumn{2}{c}{ Total } \\
\hline High constraints & $2.58(0.47)$ & {$[2.34,2.82]$} & $3.13(0.53)$ & {$[2.88,3.37]$} & $2.85(0.57)$ & {$[2.68,3.02]$} \\
Medium constraints & $2.41(0.52)$ & {$[2.17,2.66]$} & $2.45(0.40)$ & {$[2.22,2.68]$} & $2.43(0.45)$ & {$[2.26,2.60]$} \\
Total & $2.50(0.49)$ & {$[2.33,2.67]$} & $2.78(0.58)$ & {$[2.62,2.96]$} & $2.64(0.55)$ & {$[2.51,2.78]$} \\
\hline
\end{tabular}

Hypothesis 1 can be confirmed when performance was measured with creative originality: Task constraints interact with incubation periods such that high task constraints create the context for incubation gains. That is, (a) incubation gains are seen in groups with highly constrained tasks and (b) incubation gains are reduced when tasks have medium constraints.

\section{Creative productivity}

Overall scores on the creative productivity measure ranged from $14-85$ points. The pattern of results indicates an interaction effect such that the group with an incubation period while working on a medium constrained task performed worse than the other groups (see Figure 3). These results indicate that when performance was measured by creative productivity, incubation has negative consequences when the task is less constrained. This interaction was, however, not significant ( $p>$ .05; see Table 4). 


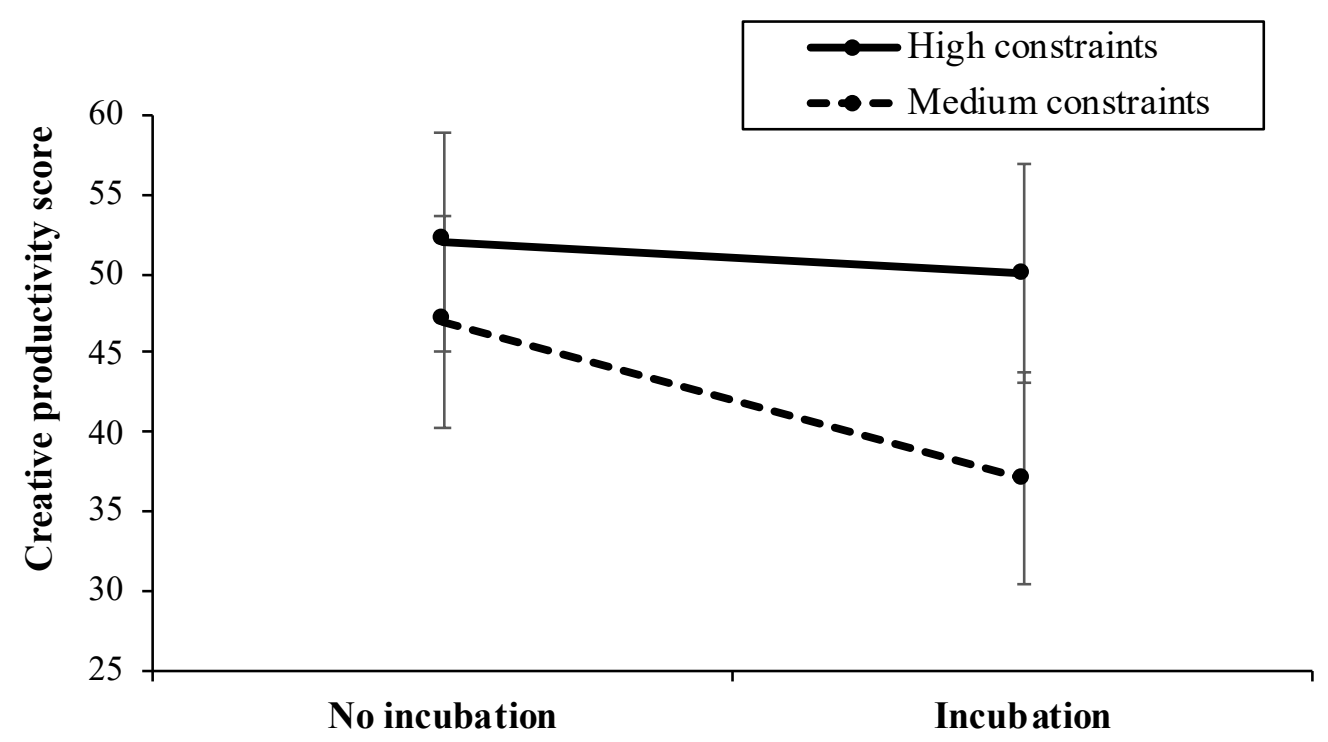

Figure 3. The effects of task constraints and incubation on creative productivity scores.

The groups with medium task constraints were found to perform worse than the groups with high task constraints (see Table 5; $\mathrm{d}=-0.70$ ).

A significant main effect was found for the task constraints variable, but not for incubation $(p>.05)$. Participants who worked on a task with medium constraints performed significantly worse compared to those who worked on a task with high constraints.

Table 4. Summarizes the two-way ANOVA statistics for creative productivity.

\begin{tabular}{lccccc}
\hline & \multicolumn{5}{c}{ ANOVA } \\
Creative productivity & $\mathrm{N}$ & $\mathrm{df}$ & $\mathrm{F}$ ratio & sig & $\eta 2$ \\
Interaction (I x C) & 64 & 1 & 1.33 & .254 & 0.02 \\
Constraints (C) & 64 & 1 & 7.45 & $.008^{*}$ & 0.11 \\
Incubation (I) & 64 & 1 & 3.06 & .085 & 0.49 \\
${ }^{*} \mathrm{p}<.05,{ }^{* *} \mathrm{p}<.001$. & & & & \\
\hline
\end{tabular}

Hypothesis 2 cannot be confirmed: Task constraints were not found to interact with incubation periods as measured with creative productivity. However, there was an overall effect of task constraints on creative productivity. Performance combined with incubation suffered when the tasks were less constrained, suggesting that medium constraints create the context for interference, but further research is needed.

Table 5. Means and confidence intervals by group as measured by creative productivity.

\begin{tabular}{lcccccc}
\hline & \multicolumn{6}{c}{ Creative productivity } \\
\cline { 2 - 8 } & \multicolumn{2}{c}{ No incubation } & \multicolumn{2}{c}{ Incubation } & \multicolumn{2}{c}{ Total } \\
\hline & $\mathrm{M}(S D)$ & $95 \% \mathrm{CI}$ & $\mathrm{M}(S D)$ & $95 \% \mathrm{CI}$ & $\mathrm{M}(S D)$ & $95 \% \mathrm{CI}$ \\
High constraints & 52.44 & & 50.37 & & 49.81 & \\
& $(14.01)$ & {$[45.55,59.32]$} & $(11.37)$ & {$[43.49,57.26]$} & $(12.63)$ & {$[46.54,56.28]$} \\
Medium constraints & 47 & & 37 & & 41.69 & \\
& $(16.27)$ & {$[39.89,54.11]$} & $(13.13)$ & {$[39.32,43.68]$} & $(15.31)$ & {$[37.12,46.88]$} \\
Total & 49.81 & & 43.48 & & 46.55 & \\
\hline
\end{tabular}




\section{Summary of the results}

Highly constrained tasks increased both the originality and productivity of creative solutions. Incubation periods raised measures of creative originality but did not significantly impact creative productivity. There was a significant interaction between task constraints and incubation on the creative originality measure.

Taken together, these results demonstrate that highly constrained tasks create the context for incubation periods to increase creative originality. When a task has medium constraints, incubation does not significantly impact creative originality. High task constraints are also beneficial to creative productivity as performance suffered when the task was less constrained. The pattern of results for creative productivity suggests an interaction where incubation periods interrupt creative productivity, particularly when tasks are less constrained. However, without the interaction effect being significant this result cannot be confirmed and must be explored in later experiments with a larger sample of participants.

All measures of creativity benefitted from high task constraints so this effect must be explored in further detail. It is also notable that the results differed to such an extent for the two measures of creativity and this is in accordance with the literature that suggests that they measure different aspects of creativity.

\section{Discussion}

The purpose of this experiment was to investigate whether the effects of incubation periods are dependent on having highly constrained creative tasks. The results show that high task constraints lead to higher creative originality and productivity scores but reducing the task constraints decreases creative originality and productivity. Creative originality increased when an incubation period was paired with a highly constrained creative task, but incubation periods did not influence the outcome when paired with less constrained creative tasks.

An interaction effect between incubation and constraints was confirmed on the creative originality measure, but not on the creative productivity measure, even though the data trends suggested an interaction. Interestingly, the incubation period that allowed participants to generate more original creative solutions may have reduced creative productivity. The creative productivity measure relies highly on how many ideas were generated, so it is likely that the participants who generated highly original ideas, did not necessarily produce a large number of ideas. These results also indicate that if the task has medium constraints, an incubation period will not benefit originality and may even interfere with creative productivity. The lack of correlation between the two dependent measures of creativity supports this idea.

\section{Effects of incubation and task constraints on creative originality.}

These results support the idea that incubation is a type of productive mind wandering, an active cognitive process of spontaneous, highly context-dependent thought (Christoff et al., 2016). The context needed to generate more creative solutions is a clearly defined creative task for the mind to work on during incubation. Providing a constrained creative task allows cognitive processes to start compiling a solution during an incubation period. Constraints set before the incubation period appear to limit mind wandering in a deliberate but helpful way, allowing spontaneous processing during incubation. Medium task constraints that enable participants to change their choice may allow more creative freedom but use up more cognitive processing to make a choice. Consequently, more cognitive processing becomes devoted to contemplating choice instead of producing new and varied solutions (Dijksterhuis et al., 2006), thus impairing creative productivity and interrupting the generation of original ideas during the incubation period. 
Creative originality was measured using the three best ideas from each participant, defined as the most original yet appropriate responses (Amabile, 1982; Benedek et al., 2013). High task constraints resulted in more original ideas overall, but in combination with an incubation period, scores on creative originality were even higher. The best ideas of those who experienced an incubation period while working on an unchangeable AUT task were more creative compared to the best ideas all other groups. All other combinations of task constraints and incubation resulted in lower measures of creative originality.

Taken together, the results suggest that an incubation period will only be beneficial to creativity when a task is deliberately and consciously constrained. The conscious processing of a specific task will allow the mind to continue working on the problem "while doing other things". The possibility of switching tasks adds uncertainty to the creative problem and this is not beneficial to creative incubation.

\section{The effects of task constraints and incubation on creative productivity}

Creative productivity measures how well participants are able to follow instructions and relies highly on cognitive control. The measure of creative productivity is sensitive to the number of creative ideas but is less a measure of the quality of ideas. Having a changeable task had a negative effect on creative productivity, and an incubation period seemed to have magnified this negative effect, although the interaction was not significant. When measured with creative productivity the group with medium task constraints and an incubation period performed worse than all other groups.

The differing effects of incubation periods on the two measures of creative performance are interesting, but perhaps not surprising. The two measures were selected for this experiment because they seem to measure different aspects of creativity and different cognitive processes needed to generate creative solutions (Silvia, 2011). Spontaneous processing during incubation would result in more original ideas leading to higher scores on the measures of creative originality (the top three index). However, creative productivity relies on cognitive control, and an incubation period allowing spontaneous processing did not benefit performance when measured in terms of productivity. Varying task constraints, therefore, affect spontaneous processing differently during incubation periods. Thus, a highly constrained task creates a context that allows spontaneous processing to work towards finding more original creative solutions. The changeable task, on the other hand, may have used processing space to "decide not to switch" rather than for solving the creative task.

High task constraints were beneficial to creative productivity which relies on cognitive control. Incubation periods may simply have distracted participants working on the task, decreasing productivity. When the task was less constrained, the incubation period merely made a difficult task more difficult and did not lead to more original ideas. When the task had high constraints the incubation period slightly lessened creative productivity. But, as noted in the top three measure, this group may have been less productive, although they did generate the most original ideas.

\section{Practical application of incubation and task constraints}

Incubation is an active cognitive process with limited resources and if a task is undefined cognitive processing will work on defining the task, but not solving the task. Creative tasks should, therefore, be clearly defined and explicit if incubation is intended to benefit creativity (Christoff et al., 2016; Dijksterhuis et al., 2006). In this context, it is important to keep in mind that sometimes the most important part of creative work is to define the problem. Selecting and defining projects that motivate people is extremely important in order to produce highly original work. It may be worth some agonizing about decisions in personally important creative work. Defining the problem is a creative task on its own and should be regarded as such. But worrying about decisions should not be required in all creative work. 
Some decisions are trivial and should not require much contemplation. Creative originality will benefit from spontaneous processing during incubation when a task is clear. Trivial decisions use spontaneous processing needed for incubation. So, if incubation is to be purposefully applied in creative projects, being clear as to goals and tasks is extremely important.

This means that when applying incubation to a creative project, teachers should quickly set the scope of creative problems with their students. This can be done by consciously defining the project with students when creative projects are presented. A vast amount of instructions are available to support conscious exploration at the start of creative projects (Jóhannsdóttir et al., 2012; Jónsdóttir, 2017). Developing further instructions to help students define the scope of a project is highly important to support creativity in the classroom. Instructions that include incubation periods should aim to clarify the problem as this allows spontaneous processing to continue and aid students on the path to solutions. Alternatively, teachers could set an early deadline for deciding what to work on, but a later deadline for the solution itself. Teachers should also be aware that long-term projects affect the thoughts of their students between classes. This processing can lead to incubation if spontaneous processing has a clear problem to solve, but without a clear problem spontaneous processing is not focused enough to be beneficial.

\section{Conclusions}

Goals, motivation, and choices are an important part of education but the interplay between them is complex. Being allowed to change tasks may seem like something people would prefer as a sudden spark of insight might occur during an incubation period (Gilbert \& Ebert, 2002). Changeability allows participants to try things out during the preparation period and make sure the choice is right for them. Then, during the incubation period, they might get a sudden spark of insight about the other task and then they could easily change tasks. However, the results here showed that increased choice also requires more processing, leading to worse performance on creative tasks, since more choice reduced incubation gains that allowed participants with unchangeable tasks to generate more original creative solutions.

The results of the current experiment suggest that high task constraints may clarify the goal and give the wandering thoughts a "destination" to drift to during incubation, thus leading to greater incubation gains only in the high constraints condition. Better processing during preparation might "push" the wandering thought in the right direction improving spontaneous processing during an incubation period. Further research is needed to assess what can be attributed to better cognitive processing during preparation, and spontaneous processing alone. This could be achieved by adding an experimental group that permanently selects a task after preparation but before incubation.

The purpose of this experiment was mainly to inspect the effects of task constraints on incubation and creativity. However, the main effects of task constraints on both measures of creativity are much more pronounced than expected and cannot be overlooked. Choices can be allowed in tasks using incubation to advance creativity, but only if the choice is deliberately and consciously constrained before the incubation period starts. By consciously defining a creative project before an incubation period lets the mind wonder in a beneficial way for creativity. These results indicate that, contrary to common belief, creativity may sometimes benefit from more constraints.

\section{Hugljómun í skapandi lausnaleit: Gerjun og afmörkun verkefna}

Gerjun (e. incubation) er pegar hlé á vinnu við skapandi verkefni leiðir til betri úrlausna en pegar unnið er áfram að verkefninu. Pegar hlé er gert virðist hugurinn vinna ómeðvitað áfram að pví að leita lausna. Gerjun er pannig ein tegund sjálfvakinnar hugsunar (e. spontaneous thought). Hugljómun um lausn er oft afrakstur pessa ferlis, en pá birtist lausnin skyndilega fyrir hugskotssjónum að pví virðist áreynslulaust. Að taka sér hlé frá verkefni tryggir pó ekki að gerjun eigi sér stað, heldur getur раð að hugurinn reiki stöð- 
ugt að ókláruðum verkefnum valdið hugarangri og truflað úrlausnir annarra verkefna. Pað er pví mikilvægt að rannsaka undir hvaða kringumstæðum sjálfvakin úrvinnsla verður að gerjun.

Tilraunir í hugrænni sálfræði hafa ítrekað sýnt fram á að gerjun stuðli að betri úrlausnum skapandi verkefna. Í tilraunum er gerjun framkölluð með pví að láta pátttakendur vinna að skapandi verkefnum, gera síðan hlé á peirri vinnu og sinna öðrum léttum verkefnum, en snúa sér svo aftur að fyrra verkefninu. Í pessum tilraunum eru notuð afmörkuð og skýrt skilgreind verkefni til að hafa stjórn á tilraunaaðstæðum. Verkefnið „ólíkir notkunarmöguleikar" (e. alternative uses task) er gott dæmi, en pá eru fundin ný not fyrir hversdagslega hluti eins og gaffal eða regnhlíf. Skapandi verkefni í tilraunum eru pví mjög ólík skapandi verkefnum sem finnast í skólastarfi. Pegar skapandi verkefni eru lögð fyrir nemendur hafa peir gjarnan mikið val um afmörkun verkefnis og nálgun í úrvinnslu. Að velja og afmarka viðfangsefnið krefst pó hugrænnar vinnslu sem gæti truflað pá ómeðvituðu úrvinnslu sem parf til að gerjun eigi sér stað. Til pess að hægt sé að hagnýta gerjun til að bæta úrvinnslu skapandi verkefna í hagnýtum tilgangi, eins og skólastarfi, er mikilvægt að átta sig á hvaða hlutverki afmörkun verkefnisins gegnir í pessu samhengi. Tilgangur rannsóknarinnar var pannig að skilja hvenær hlé frá verkefnavinnu styður við gerjun og leiðir til betri lausna skapandi verkefna og hvenær ekki. Sérstaklega var athugað hvort verkefnið sem unnið er að purfi að vera skýrt afmarkað til pess að gerjun geti átt sér stað, líkt og gerist í tilraunaaðstæðum. Sömuleiðis hvort minna afmarkað verkefni geti leitt til pess að hlé frá verkefni valdi truflun frekar en að stuðla að gerjun og betri lausnum.

Rannsóknin var tilraun með millihópasniði og tveimur frumbreytum. Fyrri frumbreytan var afmörkun verkefnis (mikil afmörkun eða miðlungs) og seinni frumbreytan var gerjunartímabil (hlé til staðar eða ekki). Alls voru pví fjórir tilraunahópar. Skapandi lausnir voru metnar annars vegar með skapandi nýnæmi (e. creative originality) sem byggir á meðaleinkunn bestu priggja lausna hvers pátttakanda og skapandi afköstum (e. creative productivity) sem byggir á pví að leggja saman einkunn fyrir allar einstakar lausnir pátttakanda. Pátttakendur $(N=64)$ voru nemendur í Fjölbrautaskólanum í Breiðholti og var peim raðað af handahófi í hópana fjóra, 15-17 í hvern hóp. Tilraunin fór öll fram í tölvu og hver pátttakandi vann út af fyrir sig án truflunar. Verkefnið „ólíkir notkunarmöguleikar" var notað og finna purfti upp á minnst 16 nýjum notkunarmöguleikum fyrir hversdagslegan hlut. Afmörkun verkefnis var aðgerðabundin með pví að pátttakendur gátu valið hlut til að nota í verkefninu (blöðru, blómapott, handklæði eða rör). Hjá helmingi pátttakenda var valið endanlegt (mikil afmörkun), en hinn helmingurinn gat skipt um skoðun par til peir hófu að vinna verkefnið (miðlungs afmörkun). Petta pýddi að af peim sem fengu gerjunartímabil var helmingur búinn að velja hlut endanlega (mikil afmörkun og gerjunartímabil) en hinn helmingurinn gat enn skipt um skoðun (miðlungs afmörkun og gerjunartímabil). Til samanburðar voru sambærilegir hópar sem ekki fengu gerjunartímabil (mikil afmörkun og ekkert gerjunartímabil; miðlungs afmörkun og ekkert gerjunartímabil).

Niðurstöðurnar sýndu að mikið afmarkað verkefni væri nauðsynlegt til að gerjunaráhrif kæmu fram, en pó aðeins fyrir fylgibreytuna skapandi nýnæmi. Samvirkni var á milli frumbreytanna tveggja og besti árangurinn var hjá hópnum sem leysti mikið afmarkað verkefni og fékk gerjunartímabil. Gerjunartímabil hafði ekki eins jákvæð áhrif hjá peim sem fengu miðlungs afmarkað verkefni. Skýrt skilgreind og fastsett verkefni virtust veita pað samhengi sem purfti til að gerjun ætti sér stað og leiddu til betra skapandi nýnæmis úrlausna. Pegar verkefni var minna afmarkað virtist hlé frekar valda truflun en gerjun. Athygli vakti að niðurstöður fyrir fylgibreytuna skapandi afköst voru ekki með sama hætti. Par komu fram áhrif afmörkunar og meira afmarkað verkefni leiddi til betri skapandi afkasta en minna afmarkað verkefni. 
Pessar niðurstöður hafa pýðingu pegar horft er til hagnýtingar í skólastarfi og skipulagningar skapandi verkefna. Hægt er að bjóða upp á val í skapandi verkefnum, en til að gerjunartímabil skili árangri ættu kennarar að prengja viðfangsefnið með nemendum sínum fljótlega eftir fyrirlögn. Með pví að láta nemendur skilgreina verkefnið nákvæmlega er líklegra að hlé á úrvinnslu (skipulögð eða tilfallandi) leiði til gerjunar og betri lausna.

Efnisorð: Sköpun, gerjun, sjálfvakin hugsun, afmörkun verkefna, val, prautalausnir

\section{Um höfunda}

Dóra Óskarsdóttir (thora@flr.is) er forstöðukona Fab Lab Reykjavíkur. Hún lauk BS-gráðu í sálfræði frá Háskóla Íslands 2013 og MS-prófi í sálfræðikennslu frá sama skóla 2021. Rannsóknaráhugi hennar snýr að hugrænum ferlum í skapandi lausnaleit. Í lokaverkefni sínu rannsakaði hún hvernig val og afmörkun verkefna hefur áhrif á gerjun skapandi lausna.

Elsa Eiríksdóttir (elsae@hi.is) er dósent við Menntavísindasvið Háskóla Íslands. Hún lauk BA-gráðu í sálfræði frá Háskóla Íslands 1999 og meistara- og doktorsprófi í verkfræðilegri sálfræði 2007 og 2011 frá Georgia Institute of Technology. Rannsóknir hennar hafa helst snúið að hugrænum ferlum í námi, yfirfærslu pekkingar og færni, verklegu námi og starfsnámi.

\section{About the authors}

Póra Óskarsdóttir (thora@flr.is) is the Director of Fab Lab Reykjavík. She completed a BS degree in psychology from the University of Iceland in 2013 and an MS degree in the teaching of psychology from the University of Iceland in 2021. Her research interests include creative cognition, learning, transfer, and skill acquisition. Her final thesis assessed how task constraints affected incubation during creative problem solving.

Elsa Eiríksdóttir (elsae@hi.is) is an associate professor at the University of Iceland, School of Education. She completed a BA degree in psychology from the University of Iceland in 1999 as well as a master's degree and a PhD in engineering psychology from Georgia Institute of Technology in Atlanta in 2007 and in 2011, respectively. Her research interests include learning, transfer of training, skill acquisition, and vocational education and learning. 


\section{References}

Amabile, T. M. (1982). Social psychology of creativity: A consensual assessment technique. Journal of Personality and Social Psychology, 43(5), 997-1013.

American Psychological Association. (n.d.). Incubation. In APA dictionary of psychology. Retrieved March 17, 2021, from https://dictionary.apa.org/incubation

Anwyl-Irvine, A. L., Massonnié, J., Flitton, A., Kirkham, N., \& Evershed, J. K. (2020). Gorilla in our midst: An online behavioral experiment builder. Behavior Research Methods, 52(1), 388-407. https://doi.org/10.3758/ s13428-019-01237-x

Baird, B., Smallwood, J., Mrazek, M. D., Kam, J. W., Franklin, M. S., \& Schooler, J. W. (2012). Inspired by distraction: Mind wandering facilitates creative incubation. Psychological Science, 23(10), 1117-1122. https://doi.org/10.1177/0956797612446024

Beaty, R. E., Benedek, M., Kaufman, S. B., \& Silvia, P. J. (2015). Default and executive network coupling supports creative idea production. Scientific Reports, 5, 10964. https://doi.org/10.1038/srep10964

Beghetto, R., \& Kaufman, J. (2016). Ever-broadening conceptions of creativity in the classroom. In R. Beghetto \& J. Kaufman (Eds.), Nurturing creativity in the classroom: Current perspectives in social and behavioral sciences, (pp. 67-85). Cambridge University Press. https://doi.org/10.1017/9781316212899.008

Benedek, M., \& Jauk, E. (2019). Creativity and cognitive control. In J. C. Kaufman \& R. J. Sternberg (Eds.), The Cambridge handbook of creativity (pp. 200-223). Cambridge University Press.

Benedek, M., Mühlmann, C., Jauk, E., \& Neubauer, A. C. (2013). Assessment of divergent thinking by means of the subjective top-scoring method: Effects of the number of top-ideas and time-on-task on reliability and validity. Psychology of Aesthetics, Creativity, and the Arts, 7(4), 341-349. https://doi.org/10.1037/a0033644

Berg, J. M. (2014). The primal mark: How the beginning shapes the end in the development of creative ideas. Organizational Behavior and Human Decision Processes, 125(1), 1-17. https://doi.org/10.1016/j.obhdp.2014.06.001

Bos, M. W., Dijksterhuis, A., \& van Baaren, R. B. (2008). On the goal-dependency of unconscious thought. Journal of Experimental Social Psychology, 44(4), 1114-1120. https://doi.org/10.1016/j.jesp.2008.01.001

Christoff, K., Irving, Z. C., Fox, K. C., Spreng, R. N., \& Andrews-Hanna, J. R. (2016). Mind-wandering as spontaneous thought: A dynamic framework. Nature Reviews Neuroscience, 17(11), 718-731. https://doi. org/10.1038/nrn.2016.113

Dijksterhuis, A., Bos, M. W., Nordgren, L. F., \& van Baaren, R. B. (2006). On making the right choice: the deliberation-without-attention effect. Science, 311 (5763), 1005-1007. https://doi.org/10.1126/science.1121629

Dodds, R. A., Ward, T. B., \& Smith, S. M. (2012). A review of experimental research on incubation in problem solving and creativity. In M. A. Runco (Ed.), The creativity research handbook (Vol. 3, pp. 251-284). Hampton Press.

DuPre, E., \& Spreng, R. N. (2018). Rumination is a sticky form of spontaneous thought. In K. Christoff \& K. C. R. Fox (Eds.), The Oxford handbook of spontaneous thought: Mind-wandering, creativity, and dreaming (pp. 501-520). Oxford University Press.

Eiriksdottir, E., \& Catrambone, R. (2011). Procedural instructions, principles, and examples: How to structure instructions for procedural tasks to enhance performance, learning, and transfer. Human Factors, 53(6), 749-770. https://doi.org/10.1177/0018720811419154

Gallate, J., Wong, C., Ellwood, S., Roring, R. W., \& Snyder, A. (2012). Creative people use nonconscious processes to their advantage. Creativity Research Journal, 24(2-3), 146-151. https://doi.org/10.1080/1040 0419.2012.677282

Gilbert, D. T., \& Ebert, J. E. J. (2002). Decisions and revisions: The affective forecasting of changeable outcomes. Journal of Personality and Social Psychology, 82(4), 503-514. https://doi.org/10.1037/0022-3514.82.4.503

Gilhooly, K. J. (2016). Incubation and intuition in creative problem solving. Frontiers in Psychology, 7, 1076. https://doi.org/10.3389/fpsyg.2016.01076

Gilhooly, K. J., Georgiou, G., \& Devery, U. (2013). Incubation and creativity: Do something different. Thinking \& Reasoning, 19(2), 137-149. https://doi.org/10.1080/13546783.2012.749812 
Glăveanu, V. P., \& Kaufman, J. C. (2019). Creativity. In J. C. Kaufman \& R. J. Sternberg (Eds.), The Cambridge handbook of creativity (pp. 9-26). Cambridge University Press.

Howe, C., McWilliam, D., \& Cross, G. (2005). Chance favours only the prepared mind: Incubation and the delayed effects of peer collaboration. British Journal of Psychology, 96(1), 67-93. https://doi. org/10.1348/000712604X15527

Jóhannsdóttir, I., Ragnarsdóttir, E., I., \& Hjartarson, T. (2012). Sköpun - Ritröð um grunnpætti menntunar [Creativity - Essays on the fundamental pillars of education]. Ministry of Education, Science and Culture. Námsgagnastofnun [The National Centre for Educational Materials].

Jónsdóttir, S. R. (2017). Narratives of creativity: How eight teachers on four school levels integrate creativity into teaching and learning. Thinking Skills and Creativity, 24, 127-139. https://doi.org/10.1016/j.tsc.2017.02.008

Kam, J. W., Dao, E., Stanciulescu, M., Tildesley, H., \& Handy, T. C. (2013). Mind wandering and the adaptive control of attentional resources. Journal of Cognitive Neuroscience, 25(6), 952-960. https://doi.org/10.1162/ jocn_a_00375

Killingsworth, M. A., \& Gilbert, D. T. (2010). A wandering mind is an unhappy mind. Science, 330(6006), 932. https://doi.org/10.1126/science.1192439

Klinger, E., Koster, E. H. W., \& Marchetti, I. (2018). Spontaneous thought and goal pursuit: From functions such as planning to dysfunctions such as rumination. In K. Christoff \& K. C. R. Fox (Eds.), The Oxford handbook of spontaneous thought: Mind-wandering, creativity, and dreaming (pp. 215-232). Oxford University Press.

Krys, S., Otte, K.-P., \& Knipfer, K. (2020). Academic performance: A longitudinal study on the role of goal-directed rumination and psychological distress. Anxiety, Stress, \& Coping, 33(5), 545-559. https://doi.org/1 0.1080/10615806.2020.1763141

Liu, W., Pan, Y., Luo, X., Wang, L., \& Pang, W. (2017). Active procrastination and creative ideation: The mediating role of creative self-efficacy. Personality and Individual Differences, 119, 227-229. https://doi. org/10.1016/j.paid.2017.07.033

Locke, E. A. (1996). Motivation through conscious goal setting. Applied and Preventive Psychology, 5(2), 117-124.

Locke, E. A., \& Latham, G. P. (2006). New directions in goal-setting theory. Current Directions in Psychological Science, 15(5), 265-268. https://doi.org/10.1111/j.1467-8721.2006.00449.x

Madjar, N., \& Shalley, C. E. (2008). Multiple tasks' and multiple goals' effect on creativity: Forced incubation or just a distraction? Journal of Management, 34(4), 786-805. https://doi.org/10.1177/0149206308318611

Mednick, M. T., Mednick, S. A., \& Mednick, E. V. (1964). Incubation of creative performance and specific associative priming. Journal of Abnormal Psychology, 69, 84-88. https://doi.org/10.1037/h0045994

Ministry of Education, Science and Culture (2012). The Icelandic national curriculum guide for upper secondary school: General section. Author. https:/www.government.is/library/01-Ministries/Ministry-of-Education/ Curriculum/adskr_frsk_ens_2012.pdf

Patston, T., Cropley, D., Marrone, R., \& Kaufman, J. (2018). Teacher implicit beliefs of creativity: Is there an arts bias? Teaching and Teacher Education, 75, 366-374. https://doi.org/10.1016/j.tate.2018.08.001

Ritter, S. M., \& Dijksterhuis, A. (2014). Creativity - the unconscious foundations of the incubation period. Frontiers in Human Neuroscience, 8, 215. https://doi.org/10.3389/fnhum.2014.00215

Runco, M. A., Millar, G., Acar, S., \& Cramond, B. (2010). Torrance tests of creative thinking as predictors of personal and public achievement: A fifty-year follow-up. Creativity Research Journal, 22(4), 361-368. https://doi.org/10.1080/10400419.2010.523393

Sadler-Smith, E. (2015). Wallas' four-stage model of the creative process: More than meets the eye? Creativity Research Journal, 27(4), 342-352. https://doi.org/10.1080/10400419.2015.1087277

Shalley, C. E. (1991). Effects of productivity goals, creativity goals, and personal discretion on individual creativity. Journal of Applied Psychology, 76(2), 179-185.

Silvia, P. (2011). Subjective scoring of divergent thinking: Examining the reliability of unusual uses, instances, and consequences tasks. Thinking Skills and Creativity, 6(1), 24-30. https://doi.org/10.1016/j.tsc.2010.06.001

Simonton, D. K. (2018). Spontaneity in evolution, learning, creativity, and free will: Spontaneous variation in four selectionist phenomena. In K. Christoff \& K. C. R. Fox (Eds.), The Oxford handbook of spontaneous thought: Mind-wandering, creativity, and dreaming (pp. 113-122). Oxford University Press. 
Sio, U. N., \& Ormerod, T. C. (2009). Does incubation enhance problem solving? A meta-analytic review. Psychological Bulletin, 135(1), 94-120. https://doi.org/10.1037/a0014212

Smallwood, J., \& Schooler, J. W. (2006). The restless mind. Psychological Bulletin, 132(6), 946-958. https:// doi.org/10.1037/0033-2909.132.6.946

Smallwood, J., \& Schooler, J. W. (2015). The science of mind wandering: Empirically navigating the stream of consciousness. Annual Review of Psychology, 66, 487-518. https://doi.org/10.1146/annurev-psych-010814-015331

Stawarczyk, D., Majerus, S., \& D'Argembeau, A. (2013). Concern-induced negative affect is associated with the occurrence and content of mind-wandering. Consciousness and Cognition: An International Journal, 22(2), 442-448. https://doi.org/10.1016/j.concog.2013.01.012

Torrance, E. P., \& Haensly, P. A. (2003). Assessment of creativity in children and adolescents. In C. R. Reynolds, R. W. Kamphaus, D. W. Barnett, G. Macmann, \& C. H. Skinner (Eds.), Handbook of psychological and educational assessment of children: Intelligence, aptitude, and achievement (2nd ed., pp. 584-607). The Guilford Press.

van Vugt, M. K., van der Velde, M., \& ESM-MERGE Investigators. (2018). How does rumination impact cognition? A first mechanistic model. Topics in Cognitive Science, 10(1), 175-191. https://doi.org/10.1111/ tops. 12318

Wallas, G. (1926). The art of thought. J. Cape.

Ward, T. B., \& Kolomyts, Y. (2019). Creative cognition. In J. C. Kaufman \& R. J. Sternberg (Eds.), The Cambridge handbook of creativity (pp. 175-199). Cambridge University Press.

Ward, T. B., Patterson, M. J., \& Sifonis, C. M. (2004). The role of specificity and abstraction in creative idea generation. Creativity Research Journal, 16(1), 1-9. https://doi.org/10.1207/s15326934crj1601_1

Zabelina, D. L., \& Andrews-Hanna, J. R. (2016). Dynamic network interactions supporting internally-oriented cognition. Current Opinion in Neurobiology, 40, 86-93. https://doi.org/10.1016/j.conb.2016.06.014

Póra Óskarsdóttir \& Elsa Eiríksdóttir. (2021).

Let them wonder: Incubation and task constraints in creative problem solving.

Netla - Veftímarit um uppeldi og menntun: Sérrit 2021 - Menntavika 2021.

Sótt af http://netla.hi.is/serrit/2021/menntavika_2021/04.pdf

DOI: https://doi.org/10.24270/serritnetla.2021.4 